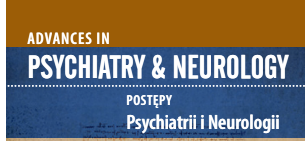

Correspondence to / Adres do korespondencji:

Marek Krzystanek

Department of Psychiatric Rehabilitation

Medical University of Silesia

Ziolowa 45/47 St.

40-635 Katowice, Poland

e-mail: krzystanekmarek@gmail.com

Submitted / Otrzymano: 05.11.2020

Accepted / Przyjęto do druku: 02.01.2021

\section{PHONOTHERAPY - A NEW \\ BIOLOGICAL TREATMENT PROPOSAL FOR THE AUGMENTATION OF PHARMACOTHERAPY IN PSYCHIATRY AND NEUROLOGY}

FONOTERAPIA - NOWA PROPOZYCJA LECZENIA BIOLOGICZNEGO DO AUGMENTACJI FARMAKOTERAPII W PSYCHIATRII I NEUROLOGII

\author{
Iwona Schuster, Monika Romańczyk, Stanisław Surma, \\ Marek Krzystanek \\ Department of Psychiatric Rehabilitation, Medical University of Silesia, Katowice, \\ Poland \\ Klinika Rehabilitacji Psychiatrycznej, Górnośląskie Centrum Medyczne SUM \\ w Katowicach, Polska
}

\begin{abstract}
Purpose: Phonotherapy is a new type of biological treatment in psychiatry. It is a modern form of music therapy in which selected musical frequencies are used for treatment, which may have a health-promoting effect. The aim of this study was to review the available research on the use of phonotherapy in medicine, as well as to present the perspectives for its use.

Views: So far, there have been several interesting studies on the effectiveness of phonotherapy in the treatment of depression, fibromyalgia and in alleviating the effects of stress. In small groups of patients, it has been shown to positively affect mood, improve anhedonia and relieve pain. All the studies involving human subjects have demonstrated the effectiveness and good tolerance of phonotherapy. An experimental study was also carried out with mouse models of dementia syndromes indicating the potential beneficial effect of phonotherapy in the treatment of dementia. The researchers found that phonotherapy can increase the number of oligodendrocytes and reduce the accumulation of $\beta$-amyloid deposits. On the basis of that research it was possible to create both an experimental and, so far, hypothetical clinical model explaining the mechanism of phonotherapy.

Conclusions: Phonotherapy is a new proposed form of biological treatment that may be effective in the treatment of depressive and stress-related disorders as well as dementia. A new mobile application, lifeAPP, discussed in the article, may be useful in conducting research on the effectiveness of phonotherapy. The results of the studies conducted to date on the influence of phonotherapy on humans are promising; however, it is necessary to conduct further studies involving larger groups of patients.
\end{abstract}

Key words: phonotherapy, augmentation, pharmacotherapy, biological treatment.

\title{
Streszczenie
}

Cel: Fonoterapia to nowa propozycja leczenia biologicznego w psychiatrii. Jest to nowoczesna postać muzykoterapii, w której do leczenia używa się wyselekcjonowanych częstotliwości muzycznych mogących mieć działanie prozdrowotne. Celem pracy był przegląd dostępnych badań dotyczących wykorzystania fonoterapii w medycynie, a także przedstawienie perspektyw zastosowania fonoterapii. Poglądy: Dotąd przeprowadzono kilka interesujących badań nad skutecznością fonoterapii w leczeniu depresji, fibromialgii i w łagodzeniu efektów stresu. Na małych grupach pacjentów stwierdzono jej pozytywny wpływ na nastrój, poprawę anhedonii i łagodzenie bólu. We wszystkich badaniach wykazano skuteczność i dobrą tolerancję fonoterapii. Przeprowadzono również badanie eksperymentalne na mysich modelach zespołów otępiennych wskazujące na potencjalnie korzystny wpływ fonoterapii w leczeniu zespołów otępiennych. Okazało się, że fonoterapia może zwiększać liczbę oligodendrocytów i zmniejszać gromadzenie się złogów $\beta$-amyloidu. Na podstawie przeprowadzonych badań udało się stworzyć zarówno eksperymentalny, jak i na razie hipotetyczny kliniczny model wyjaśniający mechanizm działania fonoterapii. 
Phonotherapy - a new biological treatment proposal for the augmentation of pharmacotherapy in psychiatry and neurology Fonoterapia - nowa propozycja leczenia biologicznego do augmentacji farmakoterapii w psychiatrii i neurologii

Wnioski: Fonoterapia jest nową formą leczenia biologicznego, która może być skuteczna w leczeniu zaburzeń depresyjnych, otępiennych i stresopochodnych. W prowadzeniu badań nad skutecznością fonoterapii przydatna może być opisana w artykule nowa aplikacja mobilna - lifeAPP. Wyniki dotychczasowych badań wpływu fonoterapii na człowieka są obiecujące, konieczne jest jednak przeprowadzenie dalszych badań na większych grupach pacjentów.

Słowa kluczowe: fonoterapia, augmentacja, farmakoterapia, leczenie biologiczne.

\section{INTRODUCTION}

Modern psychiatric treatment is mostly based on pharmacological methods. Despite the breakthrough represented by the introduction of antidepressants, antipsychotics and benzodiazepine derivatives, pharmacotherapy also has its dark side in the form of incomplete or decreasing treatment effectiveness, treatment resistance and side effects.

For example, despite the efficacy of antidepressants confirmed in clinical trials, there is a growing concern about how little the difference is between the effect of antidepressants and the placebo. The meta-analysis by Li et al. showed that in patients treated pharmacologically for depression there was not only a high level of placebo response $(\mathrm{SMD}=1.22$, which indicates a very large therapeutic effect of placebo), but also an increase in the placebo effect in recent years [1]. In the field of treating depression, one of the most recent metaanalyses showed a limited efficacy of pharmacological treatment of depression in older patients, for whom there is virtually no statistically significant difference between the treatment with an antidepressant and a placebo. Additionally, the effectiveness of treating depression in the elderly population is twice as low as in people in early and middle adulthood, and is $45.3 \%$ and $40.5 \%$ in the group of people treated with an antidepressant or a placebo, respectively [2].

The pharmacological treatment of depression is a problem that is constantly present in research. Some areas of psychopharmacology are also poorly understood, such as the pharmacological treatment of insomnia with drugs other than benzodiazepines. The limited knowledge of this issue we have derives from only a few existing publications, which suggest that only a few drugs, e.g. trazodone and doxepin, can be effective in the treatment of insomnia, and it is necessary to conduct research for other treatment for insomnia [3].

Insufficient effectiveness as well as the small number of studies documenting the effectiveness of pharmacological methods, justify the search for other methods, including biological non-pharmacological treatment for mental disorders that can be used to augment pharmacological treatment. The oldest of these is electroconvulsive

\section{WPROWADZENIE}

Obecnie leczenie w psychiatrii opiera się głównie na metodach farmakologicznych. Pomimo przełomu, jakim było wprowadzenie do psychiatrii leków przeciwdepresyjnych, przeciwpsychotycznych i pochodnych benzodiazepiny, współczesna farmakoterapia ma również swoje cienie w postaci niepełnej lub malejącej skuteczności leczenia, pojawiania się oporności na leczenie i objawów niepożądanych.

Przykładowo, pomimo potwierdzonej w badaniach klinicznych skuteczności leków przeciwdepresyjnych, coraz częściej wątpliwości budzi niewielka różnica pomiędzy efektem działania leków przeciwdepresyjnych i placebo. Metaanaliza Li i wsp. wykazała u pacjentów leczonych farmakologicznie z powodu depresji nie tylko wysoki poziom odpowiedzi placebo $(\mathrm{SMD}=1,22$, co wskazuje na bardzo duży efekt terapeutyczny), lecz także narastanie efektu placebo w ostatnich latach [1]. Pozostając w obszarze leczenia depresji, jedna $\mathrm{z}$ najnowszych metaanaliz wskazała również na ograniczoną skuteczność farmakologicznego leczenia depresji u starszych osób, u których w zasadzie nie ma statystycznie znamiennej różnicy pomiędzy leczeniem lekiem przeciwdepresyjnym i placebo. Dodatkowo sama skuteczność leczenia depresji w populacji starszych osób jest dwukrotnie mniejsza niż u osób we wczesnej i średniej dorosłości - wynosi 45,3\% i 40,5\% odpowiednio w grupie osób leczonych lekiem przeciwdepresyjnym lub placebo [2].

Leczenie farmakologiczne depresji jest problemem stale obecnym $\mathrm{w}$ badaniach naukowych. W psychofarmakologii istnieją też obszary słabo poznane, jak na przykład leczenie farmakologiczne bezsenności za pomocą leków innych niż pochodne benzodiazepiny. Ograniczona wiedza $\mathrm{w}$ tym obszarze opiera się jedynie na pojedynczych publikacjach. Wynika z nich, że zaledwie kilka leków, np. trazodon i doksepina, może być skutecznych w leczeniu bezsenności i konieczne jest prowadzenie badań nad kolejnymi sprawdzonymi sposobami leczenia bezsenności [3].

Niewystarczająca skuteczność albo niewielka liczba badań dokumentujących skuteczność metod farmakologicznych uzasadniają poszukiwanie innych, w tym też biologicznych, pozafarmakologicznych, metod leczenia zaburzeń psychicznych, które mogą być stosowane jako 
therapy (ECT), most commonly used in treatment-resistant depression. In this indication, ECT, despite the improvement over time in the effectiveness of other treatment, has no lasting effect, and even despite continued pharmacotherapy relapses are observed in a large (37\%) proportion of patients [4]. Other interesting forms of biological treatment are transcranial direct current stimulation (tDCS), which has so far been used with moderate effect in depression, and transcranial magnetic stimulation (rTMS), which, like tDCS, has moderate and shortterm efficacy in improving mood and cognitive function in people with depression [4]. Yet another form of enhancing the pharmacological treatment of depression is light therapy. This has a proven, but low, effectiveness in enhancing the antidepressive effect of antidepressants both in seasonal depression and recurrent depressive disorders [5].

Phonotherapy is a new proposal of a method augmenting pharmacological treatment, which can be used in the treatment of mental disorders. According to the authors of this paper, phonotherapy is the use of sounds of a specific frequency, acting through the sense of hearing and the auditory nerve in the brain, as well as through the action of vibrations on peripheral receptors. Thus, selective sound stimulation is another form of biological treatment in psychiatry. There are many clinical studies available in the scientific literature in which music therapy has been used with good results to support the therapy of various diseases. Research on the impact of music on humans has indicated the possibility of its multifactorial nature, in which cultural factors, music genre, sound quality, and the impact of environmental distortions, as well as personal involvement in experiencing music, may play a role [6]. The methodological flaw in this research, however, is the difficulty in operationalizing the influence of music on people and the heterogeneity of the term 'music', which includes various styles and ways of listening to it. Several studies have already appeared in the literature assessing the impact of single sounds of low or high frequency on the functioning of the human body. The aim of this study is to review the available research on the use of phonotherapy in medicine and to present the perspectives for its use.

\section{THE USE OF PHONOTHERAPY IN THE TREATMENT OF DEPRESSION}

In a study by Janzen et al. involving 19 patients (26-65 years old) with major depression, the impact of a 5 -week course of phonotherapy, combined with direct sensory stimulation of the body with vibrations, on the symptoms of depression, sleep quality and quality of life was assessed [7]. Participants were excluded if they had any augmentacja leczenia farmakologicznego. Najstarszą z nich jest terapia elektrowstrząsami (ECT), najczęściej stosowana w depresji opornej na leczenie. W tym wskazaniu ECT, pomimo poprawy w czasie skuteczności samych zabiegów, nie przynosi trwałego efektu i nawet mimo dalszego stosowania farmakoterapii nawroty są obserwowane u dużej (37\%) części pacjentów [4]. Inne interesujące formy leczenia biologicznego to przezczaszkowa bezpośrednia stymulacja prądem (tDCS), stosowana dotąd ze średnim efektem $\mathrm{w}$ depresji, oraz przezczaszkowa magnetyczna stymulacja magnetyczna (rTMS), która podobnie jak tDCS wykazuje umiarkowaną i krótkotrwałą skuteczność w poprawie nastroju i funkcji poznawczych u osób $\mathrm{z}$ depresją [4]. Jeszcze inną formą potencjalizacji farmakologicznego leczenia depresji jest światłoterapia. Ma ona potwierdzoną, ale niewielką skuteczność we wzmacnianiu efektu przeciwdepresyjnego leków przeciwdepresyjnych zarówno w depresji sezonowej, jak i w nawracających zaburzeniach depresyjnych [5].

Fonoterapia jest nową propozycją augmentacji leczenia farmakologicznego, która może być wykorzystana w leczeniu zaburzeń psychicznych. Fonoterapia w zamyśle autorów to stosowanie dźwięków o określonej częstotliwości działających poprzez zmysły słuchu i nerw słuchowy na mózg, a także poprzez działanie wibracji na receptory obwodowe. Selektywna stymulacja dźwiękiem jest więc kolejną formą biologicznego leczenia w psychiatrii. W piśmiennictwie naukowym dostępnych jest wiele badań klinicznych, w których z dobrymi efektami wykorzystywano muzykoterapię do wspomagania terapii różnych chorób. Badania wpływu muzyki na człowieka wskazały możliwość jej wieloczynnikowego wpływu, w którym rolę mogą odgrywać czynniki kulturowe, gatunek muzyki, jakość dźwięku, wpływ zakłóceń ze środowiska, jak również osobiste zaangażowanie $\mathrm{w}$ przeżywanie muzyki [6]. Wadą metodologiczną tych badań jest jednak trudny do zoperacjonalizowania wpływ muzyki na człowieka oraz niejednorodność terminu „muzyka”, obejmującego różne style i metody jej słuchania. W piśmiennictwie pojawiło się już kilka badań oceniających wpływ pojedynczych dźwięków o niskiej lub wysokiej częstotliwości na funkcjonowanie organizmu człowieka. Celem niniejszej pracy jest przegląd dostępnych badań dotyczących wykorzystania fonoterapii w medycynie, a także przedstawienie perspektyw zastosowania fonoterapii.

\section{WYKORZYSTANIE FONOTERAPII W LECZENIU DEPRESJI}

W badaniu Janzen i wsp. obejmującym 19 chorych (w wieku 26-65 lat) z dużą depresją (według kryteriów diagnostycznych DSM-V) oceniano wpływ 5-tygodniowej fonoterapii, połączonej z bezpośrednią stymulacją sensoryczną ciała wibracjami, na objawy depresji, jakość snu 
Phonotherapy - a new biological treatment proposal for the augmentation of pharmacotherapy in psychiatry and neurology Fonoterapia - nowa propozycja leczenia biologicznego do augmentacji farmakoterapii w psychiatrii i neurologii

axis I diagnosis (other than major depressive disorder, MDD) that was considered the primary diagnosis, had MDD with psychotic features, or had a diagnosis of bipolar disorder I or II. The presence of a significant axis II diagnosis (borderline, antisocial personality) and a formal diagnosis of fibromyalgia was also excluded, along with a high risk of suicide, addiction/substance abuse in the past 6 months, and the presence of any significant neurological disorder, head injury, or other unstable health conditions. Participants who changed their medication or had their dose adjusted 4 weeks prior to the inclusion procedure or who began psychological therapy in the 3 months prior to evaluation were also not eligible for the study. Other exclusion criteria included: acute and active inflammation (e.g., rheumatoid arthritis, osteoarthritis, autoimmune disease), a history of epilepsy or seizures, hearing impairment, pregnancy or breastfeeding, hemorrhage or active bleeding, thrombosis or heart disease such as hypotension, arrhythmia, or having a pacemaker, prolapsed vertebral disc, and recent back or neck injury.

The respondents listened to instrumental music with low-frequency sounds $(30-70 \mathrm{~Hz})$ embedded in it. The stimulation was performed for 30 minutes 5 times a week using a portable apparatus with built-in stereo speakers and a low frequency transducer. The transducer made it possible to perceive low-frequency vibrations, corresponding to the frequency of sounds in music, as a gentle feeling of vibration in the lower back. The Montgomery-Asberg (MADRS) scale was the instrument used for the assessment of a depressive episode in the study. Hedonia was also assessed in patients, using the Snaith-Hamilton Pleasure Scale (SHAPS). The assessment was performed by a trained psychiatrist, and response to treatment was defined as a reduction in the baseline MADRS score by at least $50 \%$. The study showed that there were significant changes in the severity of depression in 7 patients, while no changes were found in 12. In the group of people who showed improvement in the MADRS scale, a reduction in the initial severity of depression by $68 \%$ was observed, and in the SHAPS scale by as much as $80 \%$.

The second randomized controlled study conducted by the Sigurdardóttir team assessed stimulation with high-amplitude and low-frequency sound as a potential method of treating depression [8]. Exclusion criteria included pregnancy, prior electroconvulsive therapy, psychotic symptoms or signs of a serious risk of suicide or homicide. The study included 38 people: 18 were included in the test group receiving phonotherapy and conventional treatment, and 20 in the control group were only receiving conventional treatment. During the course of the project, most patients were treated with either antidepressant serotonin reuptake inhibitors (SSRIs) or serotonin norepinephrine reuptake inhibitors (SNRIs) (10/18 in the study oraz jakość życia [7]. Uczestnicy byli wykluczani z badania, jeśli mieli jakąkolwiek diagnozę z osi I (inną niż duża depresja), która była uważana za diagnozę podstawową, mieli MDD z cechami psychotycznymi albo rozpoznanie choroby afektywnej dwubiegunowej typu I lub II. Obecność istotnej diagnozy z osi II (osobowość borderline lub antyspołeczna) i formalnej diagnozy fibromialgii była również wykluczająca, wraz z wysokim ryzykiem samobójstwa, uzależnieniem/nadużywaniem substancji w ciągu ostatnich 6 miesięcy i obecnością znaczącego zaburzenia neurologicznego, urazu głowy lub niestabilny stan zdrowia. Do badania nie kwalifikowali się również uczestnicy, którzy zmienili lek lub dostosowali jego dawkę 4 tygodnie przed włączeniem lub rozpoczęli terapię psychologiczną w ciągu 3 miesięcy przed oceną. Inne kryteria wykluczenia to: ostre i aktywne stany zapalne (np. reumatoidalne zapalenie stawów, zapalenie kości i stawów, choroba autoimmunologiczna), epilepsja lub drgawki w historii choroby, upośledzenie słuchu, ciąża lub karmienie piersią, krwotok lub czynne krwawienie, zakrzepica lub choroby serca, takie jak niedociśnienie, arytmia, rozrusznik serca, wypadnięty krążek kręgowy oraz niedawne urazy pleców lub szyi.

Badani słuchali utworów muzyki instrumentalnej z osadzonymi w niej dźwiękami o niskiej częstotliwości $(30-70 \mathrm{~Hz})$. Stymulację prowadzono przez 30 minut 5 razy $\mathrm{w}$ tygodniu przy użyciu przenośnego aparatu $\mathrm{z}$ wbudowanymi głośnikami stereo i przetwornikiem niskiej częstotliwości. Przetwornik pozwalał na odbieranie wibracji o niskich częstotliwościach - odpowiadających niskim częstotliwościom dźwięków w muzyce - jako łagodnego uczucia wibracji w dolnej części pleców. Podstawową skalą służącą do oceny zaburzeń depresyjnych w badaniu była skala Montgomery-Asberg (MADRS). Za pomocą skali Snaith-Hamilton Pleasure Scale (SHAPS) u pacjentów oceniano również hedonię. Ocena była prowadzona przez przeszkolonego psychiatrę, a odpowiedź na leczenie zdefiniowano jako zmniejszenie wyjściowego wyniku MADRS co najmniej o $50 \%$. W badaniu tym wykazano, że istotne zmiany w nasileniu depresji wystąpiły u 7 osób, natomiast u 12 nie stwierdzono żadnych zmian. W grupie osób z poprawą w skali MADRS obserwowano zmniejszenie początkowego nasilenia depresji o 68\%, a w skali SHAPS aż o 80\%.

W drugim badaniu, przeprowadzonym przez zespół Sigurdardóttir, które było randomizowane i kontrolowane, oceniano z kolei stymulację impulsami dźwiękowymi o wysokiej amplitudzie i niskiej częstotliwości jako potencjalną metodę wspomagania leczenia depresji [8]. Kryteria wykluczenia obejmowały ciążę, wcześniejszą terapię elektrowstrząsową, objawy psychotyczne lub oznaki poważnego ryzyka samobójstwa lub homicydalności. Badaniem objęto 38 osób - 18 włączono do grupy badanej poddawanej fonoterapii i otrzymującej konwencjonalne leczenie, a 20 do grupy kontrolnej otrzymującej tylko konwencjonalne leczenie. W czasie trwania projektu większość chorych była leczona albo antydepre- 
group and 16/20 in the control group). The test group and one person in the control group were treated with noradrenergic and specific serotoninergic (NaSSA) drugs. Five patients in the study group and two in the control group switched from one type of antidepressant to another.

The study included 38 people: 18 were included in the study group receiving phonotherapy, and 20 in the control group receiving conventional treatment. Subjects stimulated by sounds participated in eight sessions, each of 20 minutes, for a period of 3-4 weeks. Sitting in a specially designed chair equipped with a low-frequency transducer, the person examined listened to music (all respondents listened to the same songs). In this study, sensory stimulation took place not through the back, but through a probe placed on the abdomen. Clinical effects were assessed using the Hamilton Rating Scale for Depression (HDRS-17 and HDRS-6). In the study, the study group showed a moderate $(17 \%)$ but significant $(p<0.05)$ reduction in the intensity of depressive symptoms. In both studies, people undergoing sound and sensory therapy did not report any adverse effects.

Sigurdardóttir et al. even proposed a purely hypothetical mechanism of sensory therapy, consisting in stimulating the vagus nerve in the abdominal cavity by stimulating Vater-Paccini bodies. If stimulated by vibration, this would generate afferent impulses in the vagus nerve to the cortical areas of the brain associated with depressive disorders. Unfortunately, both research models raise methodological concerns. Due to the combined use of musical and sensory stimulation, it is difficult to say which was responsible for the results. Also both studies involved very small groups of people.

\section{PHONOTHERAPY IN THE TREATMENT OF DEMENTIA}

An extremely interesting study was carried out by the Eguchi team in 2018 [9]. This was an experimental study in a mouse model of Alzheimer's disease and a model of vascular dementia. The effect of stimulating mice with high-frequency sounds $(1.875 \mathrm{~Hz})$ on cognitive functions and blood flow through the brain was investigated. It was shown that in both models, the use of high-frequency sounds significantly improved cognition, which was associated with improved blood flow in the brain. This study identified the biochemical changes in the brain induced by phonotherapy. The intervention used in the vascular dementia model significantly increased the number of vascular endothelial cells and oligodendrocyte precursor cells, while in the Alzheimer's disease model it decreased the number of microglia and amyloid- $\beta$ plaques. Both models showed an increase in the expression of endothelial nitric oxide synthase (eNOS) and neurotrophins (Figure I). syjnymi inhibitorami wychwytu zwrotnego serotoniny (SSRI), albo inhibitorami wychwytu zwrotnego serotoniny i noradrenaliny (SNRI) (10/18 z grupy badanej i 16/20 z grupy kontrolnej). Grupę badaną i jedną osobę z grupy kontrolnej leczono noradrenergicznym i specyficznie serotoninergicznym lekiem przeciwdepresyjnym (NaSSA). Pięciu chorych z grupy badanej i dwóch z grupy kontrolnej zmieniło lek przeciwdepresyjny na inny.

Badani stymulowani dźwiękami uczestniczyli w ośmiu sesjach, każda po 20 minut, przez 3-4 tygodnie. Siedząc w specjalnie zaprojektowanym krześle wyposażonym w przetwornik niskich częstotliwości, badana osoba słuchała muzyki (wszyscy badani słuchali jednakowych utworów). Stymulacja sensoryczna za pomocą wibracji odbywała się w tym badaniu nie poprzez plecy, ale przez przetwornik umieszczony na brzuchu. Efekty kliniczne oceniano za pomocą skali Hamiltona (Hamilton Rating Scale for Depression; HDRS-17 i HDRS-6). W analizie badanej grupy wykazano umiarkowane (17\%), ale znamienne $(p<0,05)$ zmniejszenie się nasilenia objawów depresyjnych. $\mathrm{W}$ obu badaniach osoby poddawane terapii dźwiękowej i sensorycznej nie raportowały działań niepożądanych.

Sigurdardóttir i wsp. zaproponowali nawet czysto hipotetyczny mechanizm działania terapii sensorycznej polegający na stymulacji nerwu błędnego w jamie brzusznej poprzez pobudzanie ciałek Vatera-Pacciniego. Pobudzanie ich przez wibrację miałoby generować $w$ nerwie błędnym aferentne impulsy do korowych obszarów mózgu związanych z zaburzeniami depresyjnymi. Niestety oba modele badawcze budzą zastrzeżenia metodologiczne. Z powodu łącznego używania stymulacji muzycznej i sensorycznej trudno stwierdzić, która z nich odpowiadała za uzyskane efekty. Oba badania były też prowadzone na bardzo małych grupach osób.

\section{FONOTERAPIA W LECZENIU OTĘPIENIA}

Niezwykle ciekawe badanie przeprowadził w $2018 \mathrm{r}$. temu zespół Eguchi [9]. Było to badanie eksperymentalne na mysim modelu choroby Alzheimera i modelu otępienia naczyniowego. Badano wpływ stymulacji myszy dźwiękami o wysokiej częstotliwości $(1,875 \mathrm{~Hz})$ na funkcje poznawcze i przepływ krwi przez mózg. Wykazano, że w obu modelach zastosowanie dźwięków o wysokiej częstotliwości znacznie poprawiło funkcje poznawcze, co było związane z poprawą przepływu krwi w mózgu. Badanie to pozwoliło określić biochemiczne zmiany w mózgu indukowane przez fonoterapię. Zastosowana interwencja w modelu otępienia naczyniopochodnego istotnie zwiększyła liczbę komórek śródbłonka naczyniowego oraz komórek prekursorowych oligodendrocytów, podczas gdy $\mathrm{w}$ modelu choroby Alzheimera zmniejszyła liczbę komórek mikrogleju i płytek amyloidu $\beta$. W obu modelach wykazano zwiększenie ekspresji śródbłonkowej syntazy tlenku azotu (eNOS) oraz neurotrofin (rycina I). 
Phonotherapy - a new biological treatment proposal for the augmentation of pharmacotherapy in psychiatry and neurology Fonoterapia - nowa propozycja leczenia biologicznego do augmentacji farmakoterapii w psychiatrii i neurologii

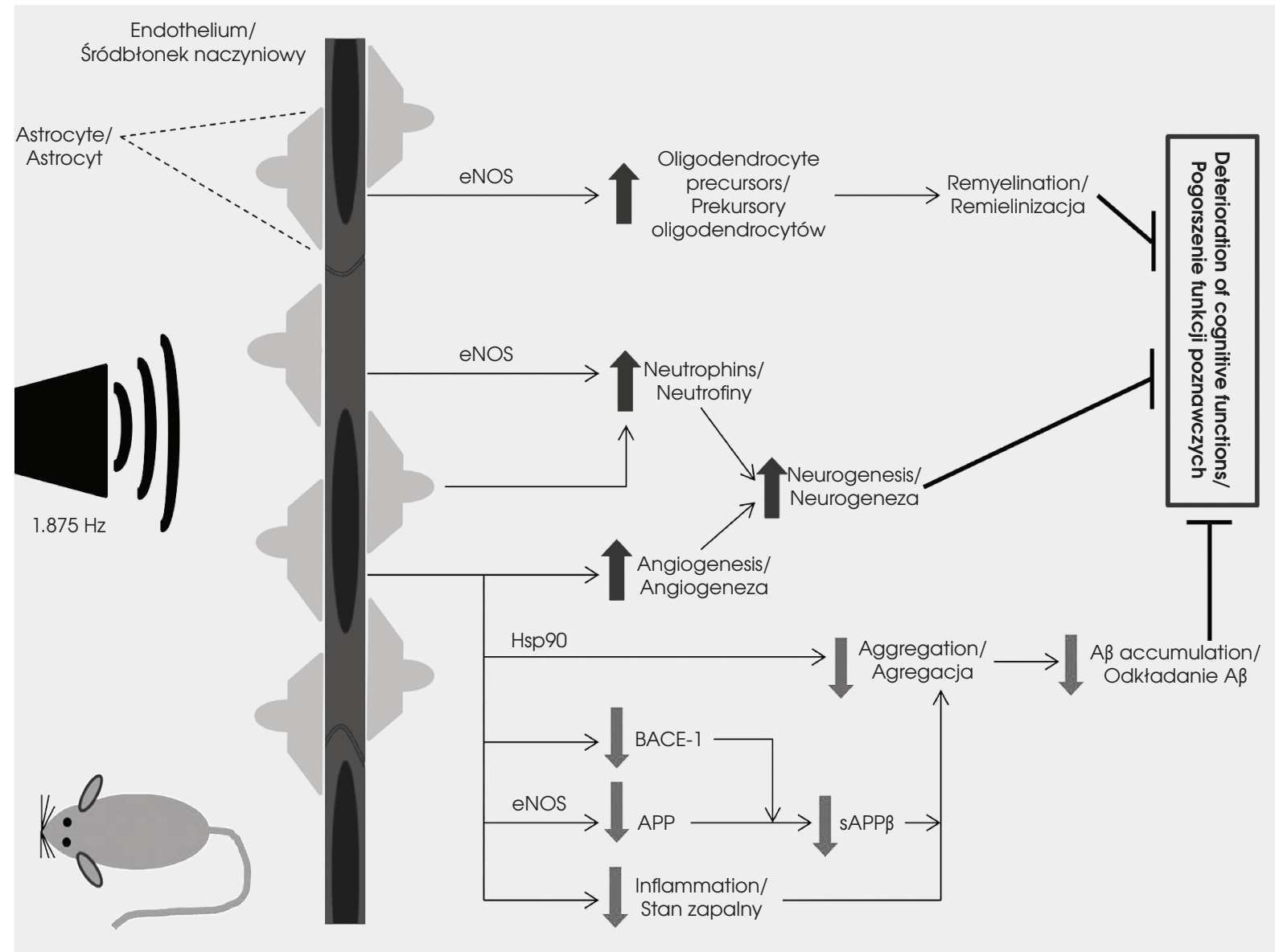

Figure I. Molecular mechanism of the influence of high-frequency sounds on the improvement of cognitive functions in an animal models of vascular dementia and Alzheimer's disease. eNOS - endothelial nitric oxide synthase, Hsp90 - heat shock protein 90, BACE-1 - $\beta$-secretase 1, APP - amyloid precursor protein, SAPP $\beta$ - secreted $\beta$ amyloid precursor protein, $A \beta$ - amyloid $\beta$. Based on Eguchi et al. (9)

Rycina I. Molekularny mechanizm wpływu dźwięków o wysokiej częstotliwości na poprawę funkcji poznawczych w zwierzęcym modelu otępienia naczyniopochodnego i choroby Alzheimera. eNOS - śródbłonkowa syntaza tlenku azołu, Hsp90 - białko szoku cieplnego 90, BACE-1 - $\beta$-sekretaza 1, APP - białko prekursorowe amyloidu, sAPP $\beta$ - wydzielane białko prekursora amyloidu $\beta, A \beta-$ amyloid $\beta$. Na podstawie Eguchi i wsp. (9)

The increases in oligodendrocyte neurogenesis and neurotrophin expression observed in mice correlated with eNOS expression; these effects were not seen in eNOS knockout mice. This research opens the possibility of obtaining similar effects when using phonotherapy in humans.

\section{THE USE OF PHONOTHERAPY IN THE TREATMENT OF FIBROMYALGIA}

Fibromyalgia is a disorder which borders psychiatry, neurology and internal diseases. From the point of view of psychiatry, it frequently meets the criteria for somatization disorder. One of the first analyses assessing the impact of phonotherapy on pain in somatization was the study by Chesky et al. conducted in 1997 with the participation of 26 patients [10] who were stimulated
Obserwowane u myszy zwiększenie neurogenezy oligodendrocytów i ekspresji neurotrofin korelowały z ekspresją eNOS; efektów tych nie obserwowano u myszy z usuniętym genem eNOS. Badane to otwiera możliwość uzyskiwania podobnych efektów pod wpływem stosowania fonoterapii u ludzi.

\section{WYKORZYSTANIE FONOTERAPII W LECZENIU FIBROMIALGII}

Fibromialgia leży w zakresie zainteresowania psychiatrii, neurologii i chorób wewnętrznych. Z punktu widzenia psychiatrii spełnia oba kryteria zaburzenia somatyzacyjnego. Jedną z pierwszych analiz oceniających wpływ fonoterapii na ból w tej jednostce chorobowej było badanie Chesky'ego i wsp. przeprowadzone w 1997 r. z udziałem 26 chorych [10]. W badaniu tym stymulowano 
with low-frequency sound $(60-300 \mathrm{~Hz})$ and oscillating vibration. The subjective pain sensation was reduced after only one 30-minute session. Unfortunately no longer, follow-up study has been undertaken.

Naghdi et al. conducted a study in a group of $19 \mathrm{fe}-$ male volunteers with the mean age of 51 and an average duration of fibromyalgia of 5.76 years [11]. The persons examined underwent ten 23-minute phonotherapy treatments (twice a week for five weeks). The study did not involve a control group. During each treatment, the patients placed in lying position were stimulated with low-frequency sound $(40 \mathrm{~Hz})$. Clinical assessments were made using the Fibromyalgia Impact Questionnaire (FIQ), Jenkins Sleep Scale, Pain Disability Index, pain free sitting and standing (in minutes), and the range of motion and tension in the neck muscles. Significant improvements in fibromyalgia symptoms, sleep and pain were observed in the subjects. Both sitting and painfree standing times were significantly lengthened, and the range of cervical muscle movement increased from $25 \%$ to $75 \%$, while muscle tone changed from hypertonic to normal $(p=0.0002)$. As a result of this improvement, $73.68 \%$ of patients had their dose reduced, and $26.32 \%$ had their drug treatment discontinued completely. Also, in this case phonotherapy using low-frequency sounds did not cause any side effects.

The mechanism by which low-frequency sounds work in fibromyalgia is unknown. Hypothetically, and also in this case, Vater-Paccini bodies are stimulated with low-frequency sounds, which leads to the suppression of nociceptive transmission mediated by adenosine, acting on $\mathrm{P} 1$ purinergic receptors at the spinal cord level [11].

\section{THE USE OF PHONOTHERAPY IN THE PREVENTION OF CARDIOVASCULAR DISEASES}

Due to the limited number of studies on phonotherapy, the authors decided to discuss two more studies conducted in the field of cardiology. In the authors' opinion, this research also indirectly concerns psychiatry, as it refers to the possibility of reducing the somatic effects of distress by stimulating the nervous system with phonotherapy.

The first study was conducted by Halbert et al. [12]. It assessed the effect of the use of music with dominant low frequency sounds $(432-440 \mathrm{~Hz})$ on arterial blood pressure (BP) and heart rate in 16 people with baseline BP: systolic 120-139 mm Hg and diastolic $80-89 \mathrm{~mm} \mathrm{Hg}$. The researchers showed no effect of phonotherapy on systolic blood pressure and the heart rate variability parameter. However, it was observed that the participants of the study, when listening to the sound with a fre- chorych dźwiękiem o niskiej częstotliwości $(60-300 \mathrm{~Hz})$ i oscylującej wibracji. Wykazano, że po jednej 30-minutowej sesji doszło u nich do zmniejszenia subiektywnego odczuwania bólu. Nie prowadzono badania długoterminowego.

Naghdi i wsp. przeprowadzili z kolei badanie w grupie 19 ochotniczek (średnia wieku 51 lat) ze średnim czasem trwania fibromialgii 5,76 roku [11]. Badane osoby zostały poddane dziesięciu 23-minutowym zabiegom fonoterapii (dwa razy w tygodniu przez pięć tygodni). W badaniu nie było grupy kontrolnej. Podczas każdego zabiegu leżące pacjentki stymulowano dźwiękiem o niskiej częstotliwości $(40 \mathrm{~Hz})$. Oceny klinicznej dokonywano za pomocą kwestionariusza wpływu fibromialgii (Fibromyalgia Impact Questionnaire - FIQ), skali snu Jenkinsa, wskaźnika niepełnosprawności bólowej, oceny siedzenia i stania bez bólu (w minutach) oraz oceny zakresu ruchu i napięcia mięśni szyi. U badanych zaobserwowano znaczącą poprawę objawów fibromialigii, snu i bólu. Zarówno czas siedzenia, jak i stania bez bólu uległ znacznemu wydłużeniu, a zakres ruchu mięśni szyjnych uległ zwiększeniu z $25 \%$ do $75 \%$, podczas gdy napięcie mięśni zmieniło się $\mathrm{z}$ hipertonicznego na normalne $(p=0,0002)$. W wyniku tej poprawy u 73,68\% chorych zmniejszono dawkę leku, a u $26,32 \%$ całkowicie go odstawiono. Również w tym przypadku fonoterapia przy użyciu dźwięków o niskiej częstotliwości nie powodowała objawów niepożądanych.

Mechanizm działania dźwięków o niskiej częstotliwości w fibromialgii jest nieznany. Hipotetycznie być może również $\mathrm{w}$ tym przypadku dochodzi do pobudzania ciałek Vatera-Pacciniego dźwiękami o niskiej częstotliwości, co prowadzi do tłumienia transmisji nocyceptywnej, w której uczestniczy adenozyna działająca na receptory purynergiczne P1 na poziomie rdzenia kręgowego [11].

\section{WYKORZYSTANIE FONOTERAPII W PROFILAKTYCE CHORÓB UKŁADU KRĄŻENIA}

Z powodu bardzo małej liczby badań dotyczących fonoterapii autorzy zdecydowali się opisać jeszcze dwa badania z obszaru kardiologii. W przekonaniu autorów badania te pośrednio dotyczą również psychiatrii, mianowicie odnoszą się do możliwości zmniejszenia efektów somatycznych dystresu poprzez stymulację układu nerwowego fonoterapią.

Pierwsze z nich przeprowadzili Halbert i wsp. [12]. Oceniano w nim wpływ wykorzystania muzyki z dominującymi dźwiękami o niskiej częstotliwości $(432-440 \mathrm{~Hz})$ na tętnicze ciśnienie krwi (BP) i akcję serca u 16 osób z wyjściowym BP skurczowym 120-139 mm Hg i rozkurczowym 80-89 mm Hg. Badacze nie wykazali wpływu fonoterapii na ciśnienie skurczowe i parametr zmienności akcji serca (heart rate variability). Zaobserwowano 
Phonotherapy - a new biological treatment proposal for the augmentation of pharmacotherapy in psychiatry and neurology Fonoterapia - nowa propozycja leczenia biologicznego do augmentacji farmakoterapii w psychiatrii i neurologii

quency of $432 \mathrm{~Hz}$, had a significantly lower pulse. It is worth adding that while listening to music, a decrease in the secretion of salivary a-amylase related to stress was also observed in these patients, though the effect was not statistically significant. In the opinion of the researchers, the observed cardioprotective effect of the $432 \mathrm{~Hz}$ musical frequency may be associated with the reduction of the activity of the sympathetic nervous system by phonotherapy. The results of this study are inconsistent with the study by Urakawa et al., which showed that low-frequency music causes an increase in heart rate [13]. However, Urakawa's study used stimulation with vibrations that act on mechanoreceptors in the body, rather than musical sounds as such.

In another study, researchers sonically processed a 3.7-minute fragment of a Mozart concerto in such a way that one group listened to a piece with an increased volume of low frequencies $(<500 \mathrm{~Hz})$, and the other with an increased loudness of frequencies $>3.5 \mathrm{kHz}$ [14]. The study assessed the impact of the composition on the stress caused earlier by listening to white noise. The results were compared with the group listening to the unchanged fragment. The study found that high-frequency sounds may be of greater importance in relieving distress.

\section{PROSPECTS FOR PHONOTHERAPY AS AN AUGMENTATION TREATMENT}

The research described indicates that researchers are interested in a new area of study concerning the influence of sounds of different frequencies on receptors, and indirectly on the nervous system. As has been shown so far in small groups of patients, this action can have a real impact on improving mood, alleviating anhedonia or reducing the impact of distress on the body.

Phonotherapy as a modern form of music therapy uses sonically processed music or selected musical frequencies superimposed on pieces of music. Its influence on the nervous system takes place through hearing receptors and somatoreceptors. Phonotherapy may thus affect various activities of the different components of the central nervous system and the sympathetic/ parasympathetic part of the autonomic nervous system. This is a completely new area of research that requires further application at different frequencies and on larger samples.

The studies conducted to date are selective, few and involving small groups of patients. It has not been possible to demonstrate which frequency ranges clinically beneficial and to establish recommendations of practical importance. For these reasons alone, the conclusions drawn from the research to date are of limited importance and require confirmation in studies on larger groups of patients. Subsequent research should focus natomiast, że uczestnicy badania podczas słuchania dźwięku o częstotliwości $432 \mathrm{~Hz}$ mieli istotnie niższy puls. Warto dodać, że podczas słuchania muzyki zaobserwowano u tych pacjentów również zmniejszenie wydzielania a-amylazy ślinowej, związanej ze stresem, ale efekt ten nie był istotny statystycznie. W przekonaniu tych badaczy obserwowany kardioprotekcyjny efekt częstotliwości muzycznej $432 \mathrm{~Hz}$ może być związany ze zmniejszaniem aktywności współczulnego układu nerwowego przez fonoterapię. Wyniki tego badania są niespójne z badaniem Urakawy i wsp., w którym wykazano, że muzyka o niskich częstotliwościach powoduje przyspieszenie akcji serca [13]. W badaniu Urakawy stosowano jednak stymulację wibracjami działającymi na mechanoreceptory w ciele, a nie dźwięki muzyczne jako takie.

W kolejnym badaniu badacze poddali opracowaniu dźwiękowemu 3,7-minutowy fragment koncertu Mozarta w taki sposób, że jedna grupa badanych słuchała utworu o zwiększonej głośności niskich częstotliwości $(<500 \mathrm{~Hz})$, a druga o zwiększonej głośności częstotliwości > 3,5kHz [14]. $\mathrm{W}$ badaniu oceniano wpływ tak opracowanego utworu na stres wywołany wcześniejszym słuchaniem białego szumu. Wyniki porównywano z grupą słuchającą niezmienionego utworu. W badaniu stwierdzono, że to dźwięki o wysokiej częstotliwości mogą mieć większe znaczenie dla łagodzenia dystresu.

\section{PERSPEKTYWY DLA AUGMENTACJI LECZENIA FONOTERAPIAC}

Opisane badania wskazują na zainteresowanie badaczy nowym obszarem badań dotyczącym wpływu dźwięków o różnej częstotliwości na receptory, a pośrednio na układ nerwowy. Jak wykazano, na razie na małych grupach osób, działanie takie może mieć faktyczny wpływ na poprawę nastroju, łagodzenie anhedonii czy też zmniejszanie wpływu dystresu na organizm.

Fonoterapia, jako nowoczesna postać muzykoterapii, posługuje się muzyką opracowaną albo wyselekcjonowanymi częstotliwościami muzycznymi nałożonymi na utwory muzyczne. Jej wpływ na układ nerwowy odbywa się poprzez receptory słuchu i somatoreceptory. Fonoterapia może w ten sposób wpływać na różne czynności poszczególnych składowych ośrodkowego układu nerwowego i część współczulną/przywspółczulną autonomicznego układu nerwowego. Jest to zupełnie nowy obszar poszukiwań, który wymaga prowadzenia dalszych badań różnych częstotliwości oraz na większych grupach osób.

Dotychczasowe badania są wybiórcze, nieliczne i przeprowadzone na małych grupach pacjentów. Nie udało się wykazać, jakie zakresy częstotliwości mają korzystne znaczenie klinicznie, oraz ustalić rekomendacji o znaczeniu praktycznym. $\mathrm{Z}$ tych powodów wnioski wyciągane $\mathrm{z}$ dotychczasowych prac mają ograniczone 

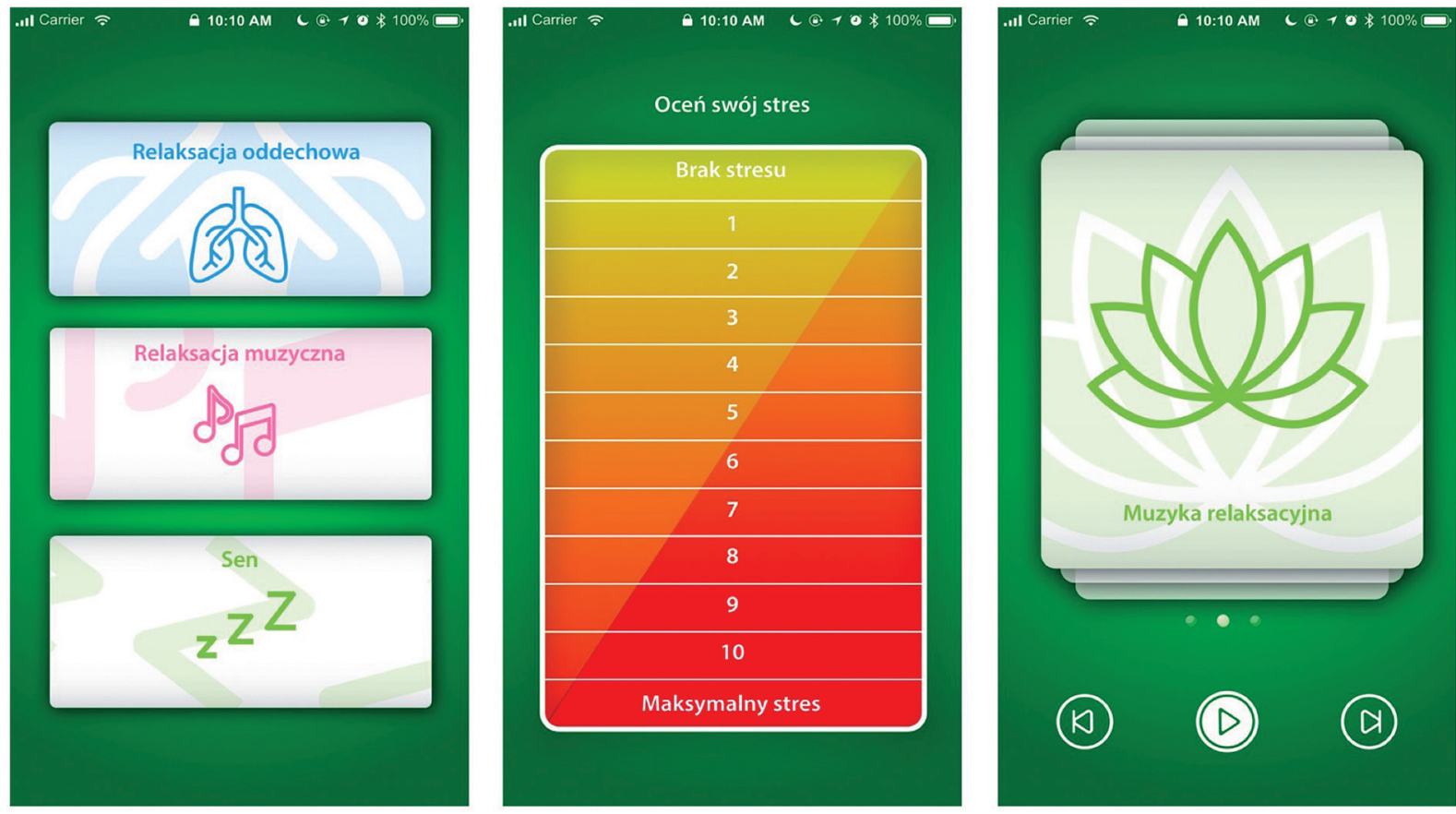

Figure II. LifeAPP screens. The application allows for selecting music pieces with different musical frequencies to be applied to different medical conditions and health complaints. The application enables the collection of medical data, for example in the form of the SUDS scale, regarding the subjective assessment of stress before and after phonotherapy session Rycina II. Ekrany aplikacji lifeAPP. Aplikacja umożliwia wybór utworów z różnymi częstotliwościami muzycznymi do badania ich w różnych wskazaniach. Aplikacja umożliwia gromadzenie danych medycznych, na przykład w formie skali SUDS dotyczącej subiektywnej oceny stresu przed fonoterapią i po fonoterapii

on the operationalization of phonotherapy, establishing the relationship between the frequency range and duration of stimulation and the therapeutic effect in various mental disorders. An important issue for hybrid treatment by combining phonotherapy with pharmacotherapy is to establish the specific effect of phonotherapy and the strength of the augmentation effect of pharmacotherapy combined with phonotherapy.

The lifeAPP mobile application can be used for this research, in which various low-frequency pieces of music have been added to the originally composed works from three genres: ambient, relaxation music and dubstep (Figure II).

Our Clinic's team started research aimed at understanding the impact of phonotherapy on sleep, symptoms of depression, pain, anxiety, neurasthenia and fatigue. Perhaps it will shed a new light on possibilities of combining pharmacotherapy with phonotherapy. In psychiatry such hybrid treatment may be a novel idea for increasing the efficacy of pharmacotherapy, especially in patients who are refractory or respond to treatment with adverse symptoms. Treatment with phonotherapy as a non-pharmacological method of biological treatment may lead to progress in psychiatric treatment. Once more clinical evidence of its effectiveness has been accumulated, phonotherapy can become a method for the augmentation of pharmacological treatment znaczenie i wymagaja potwierdzenia $\mathrm{w}$ badaniach na większych grupach pacjentów. Kolejne badania powinny skupić się na operacjonalizacji fonoterapii, ustaleniu zależności pomiędzy zakresem częstotliwości i czasem trwania stymulacji a efektem terapeutycznym $\mathrm{w}$ różnych zaburzeniach psychicznych. Istotną kwestią dla leczenia hybrydowego przez połączenie fonoterapii $\mathrm{z}$ farmakoterapią jest ustalenie swoistego efektu fonoterapii i siły efektu augmentacji farmakoterapii za pomocą fonoterapii.

Do badań tych można wykorzystać aplikację mobilną lifeAPP, w której do oryginalnie skomponowanych utworów muzycznych $\mathrm{z}$ trzech gatunków muzycznych - ambient, muzyka relaksacyjna i dubstep - dodano różne częstotliwości muzyczne o niskiej częstotliwości (rycina II).

Zespół Kliniki rozpoczął badania zmierzające do poznania wpływu fonoterpaii na sen, objawy depresji, ból, lęk, neurastenię i zmęczenie. Być może zaowocuje to nowymi możliwościami łączenia farmakoterapii $\mathrm{z}$ fonoterapią. Takie leczenie hybrydowe $\mathrm{w}$ psychiatrii może być nowym pomysłem na zwiększenie skuteczności farmakoterapii, szczególnie u pacjentów opornych albo reagujących na leczenie objawami niepożądanymi. Leczenie fonoterapią jako pozafarmakologiczną metodą leczenia biologicznego może przynieść postęp w leczeniu w psychiatrii. Fonoterapia, po zgromadzeniu dowodów na jej skuteczność, może stać się metodą augmentacji leczenia 
Phonotherapy - a new biological treatment proposal for the augmentation of pharmacotherapy in psychiatry and neurology Fonoterapia - nowa propozycja leczenia biologicznego do augmentacji farmakoterapii w psychiatrii i neurologii

or a form of treatment for mild depression, anxiety and sleep disorders. In turn, the use of phonotherapy through mobile applications may become another form of telemedicine treatment.

Right before our eyes, we may be experiencing progress in psychiatric and neurological treatment in the form of the introduction of digital forms of biological treatment, such as phonotherapy, which may become a new class of digital treatment agents (DTA). Attempts to use phonotherapy in somatic medicine are also encouraging. In fact, through phonotherapy, science can provide rational arguments for the beneficial effects of music on the human body and mind. farmakologicznego albo formą leczenia łagodnych przypadków zaburzeń depresyjnych, lękowych i zaburzeń snu. $\mathrm{Z}$ kolei stosowanie fonoterapii poprzez aplikacje mobilne może stać się kolejną telemedyczną formą leczenia.

Na naszych oczach odbywa się być może postęp w leczeniu w psychiatrii i neurologii w postaci wprowadzania cyfrowych form leczenia biologicznego, takich jak fonoterapia, które mogą stać się nową klasą cyfrowych środków leczniczych (digital treatment agents - DTA). Interesujące są również próby stosowania fonoterapii w medycynie somatycznej. W postaci fonoterapii nauka może dostarczyć racjonalnych argumentów dla dobroczynnego wpływu muzyki na organizm i umysł człowieka.

\section{Conflict of interest / Konflikt interesu}

Absent. / Nie występuje.

Financial support / Finansowanie

Absent. / Nie występuje.

\section{References / Piśmiennictwo}

1. Li F, Nasir M, Olten B, Bloch MH. Meta-analysis of placebo response in adult antidepressant trials. CNS Drugs 2019; 33: 971-980.

2. Mallery L, MacLeod T, Allen M, McLean-Veysey P, Rodney-Cail N, Bezanson E, et al. Systematic review and metaanalysis of second-generation antidepressants for the treatment of older adults with depression: questionable benefit and considerations for frailty. BMC Geriatr 2019; 19: 306.

3. Everitt H, Baldwin DS, Stuart B, Lipinska G, Mayers A, Malizia AL, et al. Antidepressants for insomnia in adults. Cochrane Database Syst Rev 2018; 5: CD010753.

4. Müller HHO, Moeller S, Lücke C, Lam AP, Braun N, Philipsen A. Vagus nerve stimulation (VNS) and other augmentation strategies for therapy-resistant depression (TRD): review of the evidence and clinical advice for use. Front Neurosci 2018; 12: 239.

5. Geoffroy PA, Schroder CM, Reynaud E, Bourgin P. Efficacy of light therapy versus antidepressant drugs, and of the combination versus monotherapy, in major depressive episodes: a systematic review and meta-analysis. Sleep Med Rev 2019; 48: 101213.

6. Howlin C. It's not just the music: Impact of the environment and individual differences on music medicine in pain settings. Proceedings of the $11^{\text {th }}$ International Conference of Students of Systematic Musicology 2018; 106-114. DOI: 10.5281 /zenodo. 1345176.

7. Janzen T, Shirawi M, Rotzinger S, Kennedy S, Bartel L. A pilot study investigating the effect of music-based intervention on depression and anhedonia. Front Psychol 2019; 10: 1038.

8. Sigurdardóttir G, Nielsen P, Rønager J, Wang A. A pilot study on high amplitude low frequency-music impulse stimulation as an add-on treatment for depression. Brain Behav 2019; 9: e01399.

9. Eguchi K, Shindo T, Ito K, Ogata T, Kurosawa R, Kagaya Y, et al. Whole-brain low-intensity pulsed ultrasound therapy markedly improves cognitive dysfunctions in mouse models of dementia - crucial roles of endothelial nitric oxide synthase. Brain Stimul 2018; 11: 959-973.

10. Chesky K, Russell I, Lopez Y, Kondraske G. Fibromyalgia tender point pain: a double-blind, placebo-controlled pilot study of music vibration using the music vibration table. J Musculoskelet Pain 1997; 5: 33-52.

11. Naghdi L, Ahonen H, Macario P, Bartel L. The effect of low-frequency sound stimulation on patients with fibromyalgia: a clinical study. Pain Res Manag 2015; 20: 21-27.

12. Halbert J, Tuyll D, Purdy C. Low frequency music slows heart rate and decreases sympathetic activity. Music \& Medicine 2018; 10: 180-185.

13. Urakawa K, Yokoyama K. Music can enhance excersice-induced sympathetic dominancy assessed by heart rate variability. Tohoku J Exp Med 2005; 206: 213-218.

14. Nakajima Y, Tanaka N, Mima T, Izumi S. Stress recovery effects of high- and low-frequency amplified music on heart rate variability. Behav Neurol 2016; 2016: 5965894. 